\title{
Reactivation Pathway of The Hydrogenase H-cluster: Density Functional Theory Study
}

\author{
Stefan Motiu \\ Cleveland State University \\ Daniela Dogaru \\ Cleveland State University \\ Valentin Gogonea \\ Cleveland State University, V.GOGONEA@csuohio.edu
}

Follow this and additional works at: https://engagedscholarship.csuohio.edu/scichem_facpub

Part of the Chemistry Commons

How does access to this work benefit you? Let us know!

\section{Publisher's Statement}

This is the accepted version of the following article: Motiu, S.; Dogaru, D.; Gogonea, V.

Reactivation pathway of the hydrogenase $\mathrm{H}$-cluster: Density functional theory study.

International Journal of Quantum Chemistry 2007, 107, 1248-1252., which has been published in final form at http://onlinelibrary.wiley.com/doi/10.1002/qua.21236/abstract

\section{Recommended Citation}

Motiu, Stefan; Dogaru, Daniela; and Gogonea, Valentin, "Reactivation Pathway of The Hydrogenase Hcluster: Density Functional Theory Study" (2007). Chemistry Faculty Publications. 326.

https://engagedscholarship.csuohio.edu/scichem_facpub/326

This Article is brought to you for free and open access by the Chemistry Department at EngagedScholarship@CSU. It has been accepted for inclusion in Chemistry Faculty Publications by an authorized administrator of EngagedScholarship@CSU. For more information, please contact library.es@csuohio.edu. 


\title{
Reactivation Pathway of the Hydrogenase H-Cluster: Density Functional Theory Study
}

\author{
STEFAN MOTIU, DANIELA DOGARU, VALENTIN GOGONEA
}

\section{Introduction}

ydrogenases are a family of enzymes that reversibly catalyze the transformation of protons and electrons to molecular hydrogen $\left(2 \mathrm{H}^{+}+\right.$
$2 \mathrm{e}^{-} \leftrightarrows \mathrm{H}_{2}$ ). The exploration for alternative energy sources has engendered great interest in hydrogenase research [1-6]. However, these enzymes appear to be inactivated by exogenous ligands [7], such as $\mathrm{O}_{2}$, and $\mathrm{OH}^{-}$. Water also binds to the active site, in the resting state, of the enzyme $[8,9], \mathrm{Fe}_{\mathrm{p}}^{\mathrm{II}}$ $\mathrm{Fe}_{\mathrm{d}}^{\mathrm{II}}$ (where $\mathrm{Fe}_{\mathrm{p}}$ is the proximal iron, and $\mathrm{Fe}_{\mathrm{d}}$ is the distal iron).

The recently detailed structures of Fe-only hydrogenases, from Clostridium pasteurianum (CPI) $[10,11]$ and Desulfovibrio desulfuricans (DdH) $[12,13]$, 


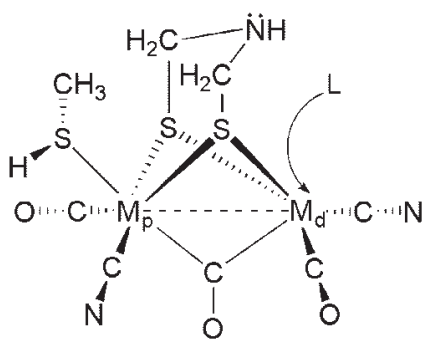

FIGURE 1. $\mathrm{H}$-cluster structure $(\mathrm{M}=\mathrm{Fe}, \mathrm{Ru})$.

offer new opportunities for understanding their functions via biochemical pathways [7, 14]. It is now possible to determine the inhibitory mechanisms of $\mathrm{O}_{2}$, and $\mathrm{OH}^{-}$by performing density functional theory (DFT) calculations on the active site of these enzymes, i.e., the H-cluster. This cluster is composed of two iron atoms bridged by the di(thiomethyl)amine (DTMA) group, coordinated by endogenous cyanide, carbon monoxide, and the bridging carbonyl $\left(\mathrm{CO}_{\mathrm{b}}\right)$ ligands. At the proximal metal, a cysteine-S bridging occurs to a $[4 \mathrm{Fe}-4 \mathrm{~S}]$ cubane, but in our investigation cysteine is replaced with $\mathrm{CH}_{3}-\mathrm{S}$, and the cubane is exchanged with $\mathrm{H}^{+}$(Fig. 1).

By performing DFT calculations on the H-cluster, with $\mathrm{OH}^{-}$, and $\mathrm{O}_{2}$ bound to $\mathrm{Fe}_{\mathrm{d}}$ (redox states, $\mathrm{Fe}^{\mathrm{I}}-\mathrm{Fe}^{\mathrm{I}}, \mathrm{Fe}^{\mathrm{I}}-\mathrm{Fe}^{\mathrm{II}}, \mathrm{Fe}^{\mathrm{II}}-\mathrm{Fe}^{\mathrm{II}}$ ), Liu and $\mathrm{Hu}$ [7] have inferred, based on agreement between the calculated and experimental vibrational frequencies of the three endogenous $\mathrm{CO}$ ligands, that $\mathrm{OH}^{-}$is the oxygen species that inhibits hydrogenases.

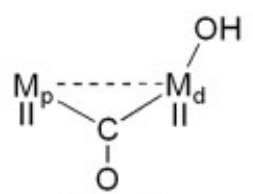<smiles>[131I-]</smiles>

$1[-1,1]$

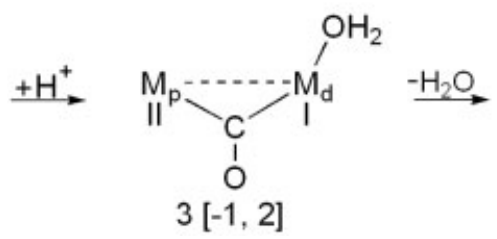

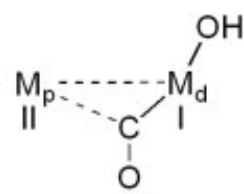

$2[-2,2]$<smiles>[M]C(C#[W])OCC</smiles>

SCHEME 1. Reactivation pathway I of Fe-only, and Ru-modified H-cluster.
TABLE I

Reaction enthalpies for elementary reaction steps of the reactivation pathway $\mathrm{I}$.

\begin{tabular}{lccr}
\hline \multirow{2}{*}{ Metal combination } & \multicolumn{3}{c}{ Reaction enthalpy } \\
\cline { 2 - 4 } & $1 \rightarrow 2$ & $2 \rightarrow 3$ & $3 \rightarrow 4$ \\
\hline $\mathrm{Fe}-\mathrm{Fe}$ & $+12.31^{\mathrm{b}}$ & -410.80 & +5.92 \\
& $+12.75^{\mathrm{c}}$ & -411.64 & +5.89 \\
$\mathrm{Fe}-\mathrm{Ru}$ & +10.02 & -406.49 & +3.42 \\
$\mathrm{Ru}-\mathrm{Fe}$ & +10.37 & -406.92 & +3.38 \\
$\mathrm{Ru}-\mathrm{Ru}$ & +14.14 & -413.96 & +4.93 \\
& +14.51 & -414.67 & +4.89 \\
& +15.90 & -412.58 & +11.93 \\
& +16.12 & -412.93 & +11.80 \\
\hline
\end{tabular}

\footnotetext{
a In $\mathrm{kcal} / \mathrm{mol}$.

${ }^{b}$ Results obtained at B3LYP/6-31+G(dp) level.

${ }^{c}$ Results obtained at B3LYP/6-311+G(d p) level.
}

\section{Methods}

The electronic structure of the H-cluster (Fe-only, and Ru-modified) was investigated by quantum mechanics (Gaussian 03 [15]), using the DFT method (B3LYP functional $[16,17])$, with a variety of bases sets. Exploratory calculations have been performed with the 6-31+G $(d, p)$ basis set, and further refined with 6-311+G $(d, p)$ basis set. For Fe and $\mathrm{Ru}$, an effective core potential (ECP) with a doublezeta polarization basis set (LANL2DZ) [18, 19] was used. In accordance with experimental and in-silico data, we selected low spin states (singlet and doublet) and low oxidation states (I and II) for the metal atoms [20-25].

\section{Results and Discussion}

Liu and $\mathrm{Hu}$ [7] showed (reactivation ${ }^{1}$ pathway I; Scheme 1) that $\mathrm{Fe}_{\mathrm{d}}^{\mathrm{II}}-\mathrm{OH}^{-}$(1) can be further reduced to $\mathrm{Fe}_{\mathrm{d}}^{\mathrm{I}}-\mathrm{OH}^{-}$(2), ${ }^{2}$ but we found that the electron transfer is endothermic $(\Delta H=+12.31 \mathrm{kcal} / \mathrm{mol}$; Table I) because the H-cluster (1) is already negatively charged ( -1 a.u.). $\mathrm{Fe}_{\mathrm{d}}^{\mathrm{I}}-\mathrm{OH}^{-}$(2) can be easily protonated to $\mathrm{Fe}_{\mathrm{d}}^{\mathrm{I}}-\mathrm{OH}_{2}$ (3) because its proton affin-

\footnotetext{
${ }^{1}$ The process whereby the $\mathrm{H}$-cluster is set free, once again, of exogenous ligands, e.g., $\mathrm{OH}^{-}, \mathrm{H}_{2} \mathrm{O}$, at the active site, $\mathrm{Fe}_{\mathrm{d}}{ }^{1}$, in its reduced form. Thus, in its reactivated state, the H-cluster is enabled to engage in its (former) catalytic $\mathrm{H}_{2}$ redox activity.

${ }^{2}$ Calculations on $\mathrm{Fe}(\mathrm{I})$ have been previously reported in Refs. $[7,14,21-24]$
} 


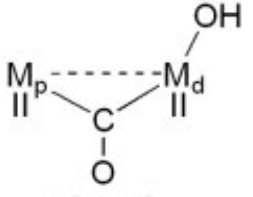<smiles></smiles>

$1[-1,1]$
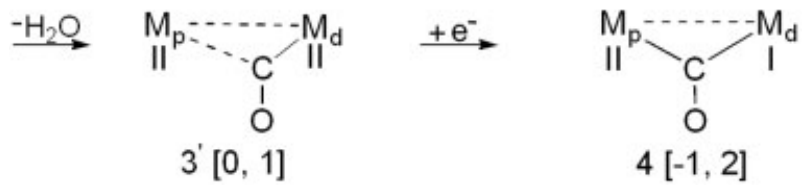

SCHEME 2. Reactivation pathway II of Fe-only, and Ru-modified H-cluster.

ity is $+410.8 \mathrm{kcal} / \mathrm{mol}$. The water dissociation from $\mathrm{Fe}_{\mathrm{d}}^{\mathrm{I}}-\mathrm{OH}_{2}(3)$ is also endothermic $(\Delta H=+5.92 \mathrm{kcal} /$ $\mathrm{mol}$ ).

Scheme 2 shows the reactivation pathway II in which the protonation step occurs first. This step proceeds because the proton affinity of $\mathrm{Fe}_{\mathrm{d}}^{\mathrm{II}}-\mathrm{OH}^{-}$ (1) is still very large $(+326.95 \mathrm{kcal} / \mathrm{mol}$, Table II). Furthermore, Scheme 2 shows that water dissociation from $\mathrm{Fe}_{\mathrm{d}}^{\mathrm{II}}-\mathrm{OH}_{2}\left(2^{\prime}\right)$ is also exothermic $(\Delta \mathrm{H}=$ $-3.22 \mathrm{kcal} / \mathrm{mol}$ ). In contrast, Cao and Hall [22] found that the removal of water from the distal iron of $\mathrm{Fe}_{\mathrm{p}}^{\mathrm{II}}-\mathrm{Fe}_{\mathrm{d}}^{\mathrm{II}}$ is rather endothermic $(\Delta H=+23 \mathrm{kcal} /$ mol).

The difference in the reaction enthalpy calculated by Cao and Hall [22], relative to our result, may stem from the fact that the optimized structure, $\mathrm{Fe}_{\mathrm{p}}^{\mathrm{II}}-\mathrm{Fe}_{\mathrm{d}}^{\mathrm{II}}\left(3^{\prime}\right)$, in Cao and Hall's study, has the bridging carbonyl ligand $\left(\mathrm{CO}_{\mathrm{b}}\right)$ midway between $\mathrm{Fe}_{\mathrm{p}}$ and $\mathrm{Fe}_{\mathrm{d}}$, which makes the H-cluster higher in energy than it is when $\mathrm{CO}_{\mathrm{b}}$ is bound (asymmetrically) closer to $\mathrm{Fe}_{\mathrm{d}}$ [Scheme 2, $\left.\left(3^{\prime}\right)\right]$. However, we were unable to find a stationary point (energy minimum) at the B3LYP/6-31+G(d,p) level for the structure with symmetrically bound $\mathrm{CO}_{\mathrm{b}}$, but we obtained a partially optimized structure by constraining only the distance between $\mathrm{CO}_{\mathrm{b}}$ and $\mathrm{Fe}_{\mathrm{p}}$ the breaking bond-at $2.147 \AA$ (the distance between $\mathrm{CO}_{\mathrm{b}}$ and $\mathrm{Fe}_{\mathrm{d}}$ was reduced from $2.040 \AA$ to $1.873 \AA$ during optimization). This quasi-symmetrical structure is $14 \mathrm{kcal} \mathrm{mol}^{-1}$ higher in energy than the structure with $\mathrm{CO}_{\mathrm{b}}$ bound asymmetrically $\left(3^{\prime}\right)$ to the two irons. Thus, a symmetrically $\mathrm{CO}_{\mathrm{b}}$ bound structure is expected to be even higher in energy. Hence, the removal of $\mathrm{H}_{2} \mathrm{O}$ (Scheme 2) is exothermic, as the $\mathrm{CO}_{\mathrm{b}}$ has been shifted toward $\mathrm{Fe}_{\mathrm{d}}$, and this facilitates exogenous ligand bond breaking
[14]. Another structural detail contributing to the difference in the reaction enthalpies, $2^{\prime} \rightarrow 3^{\prime}$, is that in the reactivation pathway of Scheme 2 (same for $\mathrm{Liu}$ and $\mathrm{Hu}$ [7]), the nonbridging sulfur bound to $\mathrm{Fe}_{\mathrm{p}}^{\mathrm{II}}$ is protonated. Also, owing to the different levels of theory used by each investigating group, inevitably different optimized geometries are obtained.

The result of this investigation, regarding water removal from $\mathrm{Fe}_{\mathrm{d}}^{\mathrm{II}}$, corroborates an antithetical reactivation pathway, that is, the reduction of $\mathrm{Fe}_{\mathrm{p}}^{\mathrm{II}}$ $\mathrm{Fe}_{\mathrm{d}}^{\mathrm{II}}\left(3^{\prime}\right)$ is exothermic (unlike Scheme 1 [22]), for the $\mathrm{CO}_{\mathrm{b}}$ is bound only to $\mathrm{Fe}_{\mathrm{d}}^{\mathrm{II}}$, and not to $\mathrm{Fe}_{\mathrm{p}}^{\mathrm{II}}$. Our results indicate that water removal from $\mathrm{Fe}_{\mathrm{d}}^{\mathrm{PI}}$ is facilitated by concerted bond breaking of $\mathrm{CO}_{\mathrm{b}}$ from $\mathrm{Fe}_{\mathrm{p}}^{\mathrm{II}}$ and bond contraction between $\mathrm{CO}_{\mathrm{b}}$ and $\mathrm{Fe}_{\mathrm{d}}^{\mathrm{II}}$ (as the bridging carbonyl migrates toward $\mathrm{Fe}_{\mathrm{d}}^{\mathrm{II}}$ ) (Table III). The reactivation of the H-cluster is complete upon reduction [26] of $\mathrm{Fe}_{\mathrm{d}}^{\mathrm{II}}$ to $\mathrm{Fe}_{\mathrm{d}}^{\mathrm{I}}$. This reduction process is highly exothermic $(\Delta H=-62.41 \mathrm{kcal} /$ mol; Table II).

This reaction pathway (Scheme 2) thermodynamically favors the reactivation of the $\mathrm{H}$-cluster, and suggests that the $\mathrm{H}$-cluster may not be permanently inhibited by $\mathrm{OH}^{-}$, or $\mathrm{H}_{2} \mathrm{O}$, nonetheless. It appears that as long as the $\mathrm{H}$-cluster is supplied protons, its reactivation shall continue.

The following bimetal combinations within the H-cluster, i.e., $\mathrm{Fe}_{\mathrm{p}}-\mathrm{Fe}_{\mathrm{d}}, \mathrm{Fe}_{\mathrm{p}}-\mathrm{Ru}_{\mathrm{d}}, \mathrm{Ru}_{\mathrm{p}}-\mathrm{Fe}_{\mathrm{d}}$, and $\mathrm{Ru}_{\mathrm{p}}-$ $R u_{d}$, were theoretically investigated (Tables I and II) to elucidate which combinations are less sensitive to $\mathrm{OH}^{-}$inhibition, and to determine whether the varied metal combinations perform thermodynamically better than the $\mathrm{Fe}-\mathrm{Fe} \mathrm{H}$-cluster.

\section{TABLE II}

Reaction enthalpies for elementary reaction steps of the reactivation pathway II.

\begin{tabular}{lcrr}
\hline \multirow{2}{*}{ Metal combination } & \multicolumn{3}{c}{ Reaction enthalpy } \\
\cline { 2 - 4 } Fe-Fe & $1 \rightarrow 2^{\prime}$ & $2^{\prime} \rightarrow 3^{\prime}$ & $3^{\prime} \rightarrow 4$ \\
& $-326.95^{\mathrm{b}}$ & -3.22 & -62.41 \\
$\mathrm{Fe}-\mathrm{Ru}$ & $-327.55^{\mathrm{c}}$ & -3.19 & -62.25 \\
$\mathrm{Ru}$ & -331.14 & +5.13 & -67.02 \\
$\mathrm{Ru}$ & -331.50 & +4.96 & -66.63 \\
$\mathrm{Ru}-\mathrm{Ru}$ & -329.56 & +10.26 & -75.59 \\
& -330.21 & +10.46 & -75.52 \\
& -328.13 & +6.06 & -62.67 \\
& -328.52 & +5.89 & -62.38 \\
\hline
\end{tabular}

\footnotetext{
${ }^{\mathrm{a}}$ In $\mathrm{kcal} / \mathrm{mol}$.

${ }^{\text {b }}$ Results obtained at B3LYP/6-31+G(dp) level.

${ }^{c}$ Results obtained at B3LYP/6-311+G(dp) level.
} 
TABLE III

Bond lengths ${ }^{a}\left(\mathrm{M}_{\mathrm{p}}-\mathrm{CO}_{\mathrm{c}}\right.$ and $\left.\mathrm{M}_{\mathrm{d}}-\mathrm{CO}_{\mathrm{c}}\right)$ for the reactant, product, and intermediates that appear in reactivation pathways I and II of $\mathrm{H}$-cluster of hydrogenase.

\begin{tabular}{|c|c|c|c|c|c|c|}
\hline \multirow[b]{2}{*}{ Metal combination } & \multicolumn{6}{|c|}{ Compound } \\
\hline & 1 & 2 & 3 & 4 & $2^{\prime}$ & $3^{\prime}$ \\
\hline \multirow[t]{2}{*}{$\mathrm{Fe}-\mathrm{Fe}$} & $2.341^{b}$ & 2.817 & 2.013 & 2.232 & 2.411 & 3.067 \\
\hline & $1.829^{c}$ & 1.807 & 1.945 & 1.850 & 1.845 & 1.819 \\
\hline \multirow[t]{2}{*}{$\mathrm{Fe}-\mathrm{Ru}$} & 2.541 & 2.935 & 2.161 & 3.710 & 2.661 & 3.250 \\
\hline & 1.935 & 1.922 & 1.977 & 1.902 & 1.909 & 1.915 \\
\hline \multirow[t]{2}{*}{$\mathrm{Ru}-\mathrm{Fe}$} & 2.141 & 2.083 & 2.072 & 2.110 & 1.942 & 1.991 \\
\hline & 1.961 & 2.005 & 1.984 & 1.947 & 2.503 & 2.487 \\
\hline \multirow[t]{2}{*}{$\mathrm{Ru}-\mathrm{Ru}$} & 2.458 & 2.245 & 2.159 & 2.170 & 2.609 & 3.362 \\
\hline & 1.966 & 2.032 & 2.019 & 2.009 & 1.930 & 1.918 \\
\hline
\end{tabular}

${ }^{a} \ln \AA$.

${ }^{b}$ Results obtained at B3LYP/6-31+G(dp) level for $\mathrm{M}_{\mathrm{p}}-\mathrm{CO}_{\mathrm{c}}$.

${ }^{c}$ Results obtained at B3LYP/6-31+G(dp) level for $\mathrm{M}_{d}-\mathrm{CO}_{\mathrm{c}}$.

Table I lists reaction enthalpies for the reactivation pathway I. For $\mathrm{Fe}_{\mathrm{p}}-\mathrm{Ru}_{\mathrm{d}}$ modified $\mathrm{H}$-cluster the electron transfer is slightly less endothermic $(+2.29$ $\mathrm{kcal} / \mathrm{mol}$ ) than for $\mathrm{Fe}_{\mathrm{p}}-\mathrm{Fe}_{\mathrm{d}} \mathrm{H}$-cluster. The proton affinities for $\mathrm{Ru}_{\mathrm{p}}-\mathrm{Fe}_{\mathrm{d}}$, and $\mathrm{Ru}_{\mathrm{p}}-\mathrm{Ru}_{\mathrm{d}}$ are slightly larger than for Fe-only, except $\mathrm{Fe}_{\mathrm{p}}-\mathrm{Ru}_{\mathrm{d}}$. However, in the $\mathrm{H}_{2} \mathrm{O}$ removal step, the bimetals $\mathrm{Fe}_{\mathrm{p}}-\mathrm{Ru}_{\mathrm{d}}$ and $\mathrm{Ru}_{\mathrm{p}}-\mathrm{Fe}_{\mathrm{d}}$ release water more readily than the Feonly cluster. Conversely, calculations on Ru-only $\mathrm{H}$-cluster indicate that $\mathrm{Ru}_{\mathrm{d}}$ binds water more firmly than $\mathrm{Fe}_{\mathrm{d}}$ (Table I).

In contrast, for the reactivation pathway II, protonation of bimetal combinations, i.e., $\mathrm{Fe}_{\mathrm{p}}-\mathrm{Ru}_{\mathrm{d}}$, $\mathrm{Ru}_{\mathrm{p}}-\mathrm{Fe}_{\mathrm{d}}$, and $\mathrm{Ru}$-only, is highly exothermic (similar to the Fe-only H-cluster). However, water removal is endothermic for these bimetal combinations. Subsequently, the reduction process (Scheme 2 ) necessitates similar enthalpies of reaction for most bimetal combinations (Table II) mentioned above except for $\mathrm{Ru}_{\mathrm{p}}-\mathrm{Fe}_{\mathrm{d}}$ which is slightly more exothermic.

\section{Conclusions}

Reactivation pathway I consists of an endothermic electron transfer step, followed by an exothermic protonation step, and then an endothermic water removal step. For reactivation pathway II, the $\mathrm{H}$-cluster protonation occurs first, followed by water removal, and then by electron transfer with all steps being exothermic.

Finally, we propose a reaction pathway for the reactivation of the hydrogenase $\mathrm{H}$-cluster, in which all individual reaction steps are thermodynamically favored (Scheme 2).

\section{ACKNOWLEDGMENTS}

Computational resources have been provided by the National Center for Supercomputer Applications (University of Illinois) and the Ohio Supercomputer Center.

\section{References}

1. Melis, A.; Zhang, L.; Forestier, M.; Ghirardi, M. L.; Seibert, M. Plant Physiol 2000, 122, 127.

2. Adams, M. W. W. Biochim Biophys Acta 1990, 1020, 115.

3. Adams, M. W. W.; Stiefel, E. I. Science 1998, 282, 1842.

4. Albracht, S. P. J. Biochim Biophys Acta 1994, 1118, 167.

5. Happe, R. P.; Roseboom, W.; Pierik, A. J.; Albracht, S. P.; Bagley, K. A. Nature 1997, 385, 126.

6. Cammack, R. Nature 1999, 397, 214.

7. Liu, Z.-P.; Hu, P. J Am Chem Soc 2002, 124, 5175.

8. Lemon, B. J.; Peters, J. W. Biochemistry 1999, 38, 12969.

9. Lemon, B. J.; Peters, J. W. J Am Chem Soc 2000, 122, 3793.

10. Meyer, J.; Gagnon, J. Biochemistry 1991, 30, 9697.

11. Peters, J. W.; Lanzilotta, W. N.; Lemon, B. J.; Seefeldt, L. C. Science 1998, 282, 1853.

12. Nicolet, Y.; Piras, C.; Legrand, P.; Hatchikian, E. C.; Fontecilla-Camps, J. C. Structure 1999, 7, 13.

13. Nicolet, Y.; De Lacey, A. L.; Vernede, X.; Fernandez, V. M.; Hatchikian, E. C.; Fontecilla-Camps, J. C. J Am Chem Soc 2001, 123, 1596.

14. Liu, Z.-P.; Hu, P. J Chem Phys 2002, 117, 8177.

15. Frisch, M. J.; Trucks, G. W.; Schlegel, H. B.; Scuseria, G. E.; Robb, M. A.; Cheeseman, J. R.; Montgomery, J. A., Jr.; 
Vreven, T.; Kudin, K. N.; Burant, J. C.; Millam, J. M.; Iyengar, S. S.; Tomasi, J.; Barone, V.; Mennucci, B.; Cossi, M.; Scalmani, G.; Rega, N.; Petersson, G. A.; Nakatsuji, H.; Hada, M.; Ehara, M.; Toyota, K.; Fukuda, R.; Hasegawa, J.; Ishida, M.; Nakajima, T.; Honda, Y.; Kitao, O.; Nakai, H.; Klene, M. L., X.; Knox, J. E.; Hratchian, H. P.; Cross, J. B.; Bakken, V.; Adamo, C.; Jaramillo, J.; Gomperts, R.; Stratmann, R. E.; Yazyev, O.; Austin, A. J.; Cammi, R.; Pomelli, C.; Ochterski, J. W.; Ayala, P. Y.; Morokuma, K.; Voth, G. A.; Salvador, P.; Dannenberg, J. J.; Zakrzewski, V. G.; Dapprich, S. D., A. D.; Strain, M. C.; Farkas, O.; Malick, D. K.; Rabuck, A. D.; Raghavachari, K.; Foresman, J. B.; Ortiz, J. V.; Cui, Q.; Baboul, A. G.; Clifford, S.; Cioslowski, J.; Stefanov, B. B.; Liu, G.; Liashenko, A.; Piskorz, P.; Komaromi, I.; Martin, R. L.; Fox, D. J.; Keith, T.; Al-Laham, M. A.; Peng, C. Y.; Nanayakkara, A.; Challacombe, M.; Gill, P. M. W.; Johnson, B.; Chen, W.; Wong, M. W.; Gonzalez, C.; Pople, J. A. Gaussian: Wallingford, CT, 2004.
16. Becke, A. D. J Chem Phys 1993, 98, 5648.

17. Lee, C.; Yang, W.; Parr, R. G. Phys Rev B 1988, 37, 785.

18. Hay, P. J.; Wadt, W. R. J Chem Phys 1985, 82, 270.

19. Wadt, W. R.; Hay, P. J. J Chem Phys 1985, 82, 284.

20. De Lacey, A. L.; Stadler, C.; Cavazza, C.; Hatchikian, E. C.; Fernandez, V. M. J Am Chem Soc 2000, 122, 11232.

21. Fan, H.-J.; Hall, M. B. J Am Chem Soc 2001, 123, 3828.

22. Cao, Z.; Hall, M. B. J Am Chem Soc 2001, 123, 3734.

23. Bruschi, M.; Fantucci, P.; De Gioia, L. Inorg Chem 2002, 41, 1421.

24. Bruschi, M.; Fantucci, P.; De Gioia, L. Inorg Chem 2003, 42, 4773.

25. Pierik, A. J.; Hagen, W. R.; Redeker, J. S.; Wolbert, R. B. G.; Boersma, M.; Verhagen, M. F. J. M.; Grande, H. J.; Veeger, C.; Mutsaers, P. H. A.; Sands, R. H.; Dunham, W. R. Eur J Biochem 1992, 209, 63.

26. Peters, J. W. Curr Opin Struct Biol 1999, 9, 670. 